\title{
Генерация терагерцового излучения в нелинейнооптических кристаллах ВBO, LBO и КТР под действием интенсивного лазерного излучения
}

\author{
Н.А. Николаев ${ }^{1)}$, А.А. Мамрашев ${ }^{1)}$, Ю.М. Андреев ${ }^{2)}$, Г.В. Ланский ${ }^{2)}$ \\ ${ }^{1}$ Институт автоматики и электрометрии СО РАН, \\ Новосибирск, 630090, пр. Академика Коптюга, д. 1 \\ ${ }^{2}$ Институт мониторинга климатических и экологических систем СО РАН, \\ Томск, 634055, пр. Академический, 10 / 3. \\ тел: +7 (383) 330-84-53, эл. nочта: nazar@iae.nsk.su
}

DOI 10.34077/RCSP2019-77

Нелинейные кристаллы бета-борат бария $\left(\beta-\mathrm{BaB}_{2} \mathrm{O}_{4}, \mathrm{BBO}\right)$, триборат лития $\left(\mathrm{LiB}_{3} \mathrm{O}_{5}, \mathrm{LBO}\right)$ и титанил-фосфат калия $\left(\mathrm{KTiOPO}_{4}, \mathrm{KTP}\right)$ широко используются в качестве преобразователей частоты лазерного излучения ближнего ИК-диапазона в пределах окон их прозрачности. На длине волны 1064 нм их нелинейные коэффициенты принимают относительно невысокие значения: $\mathrm{d}_{22}= \pm 2,3$ пм/B (BBO), $\mathrm{d}_{32}= \pm 0,85$ пм/B (LBO) $\mathrm{d}_{33}=10,7$ пм/B (KTP) [1], однако, благодаря высокой лучевой прочности, в особенности боратов, и малому поглощению, они до сих пор остаются популярным. Учитывая эффективность кристаллов для преобразования частот в оптическом диапазоне, можно предположить, что они также применимы и для генерации разнолистной частоты (ГРЧ) в терагерцовый (ТГц) или миллиметровый (мм) диапазоны, поскольку данный процесс опирается на те же нелинейные коэффициенты. Принимая во внимание прогресс в развитии высокоинтенсивных лазерных установок, мотивацией данного исследования является перспектива создания компактных и мощных источников ТГц- и мм-диапазона, основанных на принципах нелинейной кристаллооптики и обладающих высокой спектральной яркостью.

В данной работе с помощью импульсного терагерцового спектрометра (ЦКП «Спектроскопия и оптика», ИАиЭ СО РАН [2]) изучены оптические свойства кристаллов BBO, LBO и КTР в диапазоне $0,2-2$ ТГц при комнатной $(295 \mathrm{~K})$ и криогенной $(77 \mathrm{~K})$ температурах. Определены дисперсионные свойства показателей преломления и аппроксимированы в виде уравнений Селмейера, по которым рассчитаны кривые фазового синхронизма для ГРЧ лазерного излучения ближнего ИК-диапазона (Рис. 1).
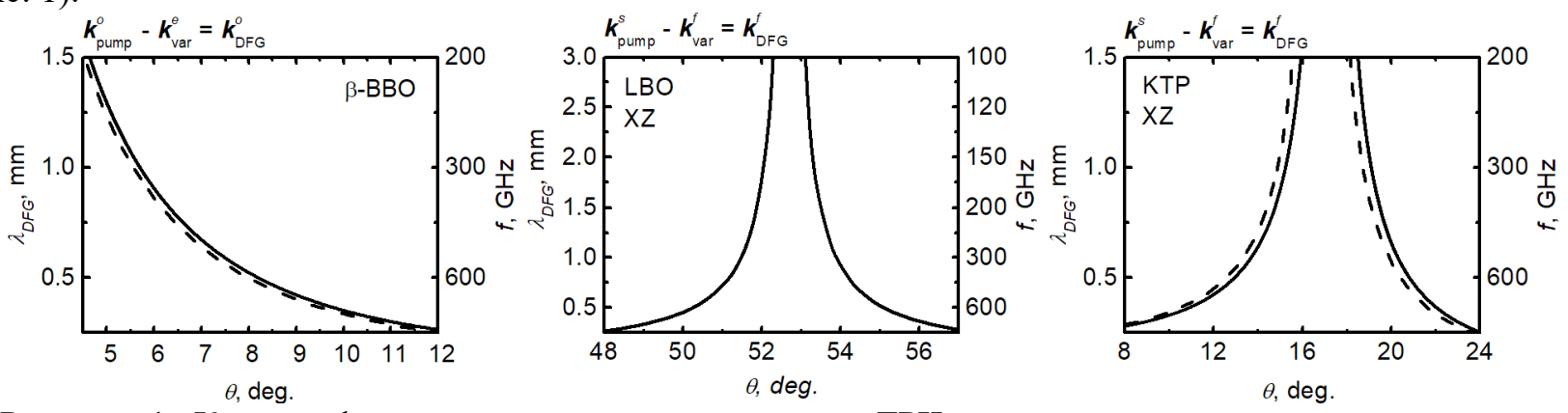

Рисунок 1. Кривые фазового синхронизма процесса ГРЧ при накачке лазерным излучением в окрестности 1064 нм для кристаллов BBO, LBO (плоскость XZ) и КTP (плоскость XZ) при температуре $295 \mathrm{~K}$ (сплошные кривые) и $77 \mathrm{~K}$ (штриховые кривые). Сверху отображен тип коллинеарного фазового синхронизма.

В результате установлено, что у кристаллов КТР и ВВО условия фазового синхронизма не исчезают с криогенным охлаждением, а коэффициенты поглощения резко падают с сохранением существенной анизотропии. Таким образом, ГРЧ в ТГц спектральный диапазон возможен. Картина изменения свойств кристаллов LBO с охлаждением чрезвычайно сложна, и условия фазового синхронизма перестают выполняться при криогенных температурах. Однако, обнаруженная температурная стабильность оси $Z$ и значительное падение оптических потерь для волн с поляризацией параллельной осям $X$ и $Y$ открывают новые перспективы использования данного кристалла для устройств ТГц- и мм-диапазонов. Обсуждаются детали полученных результатов и потенциальные характеристики преобразователей в ТГц-диапазон.

\section{Лumepamypa}

[1] Dmitriev V.G., Gurzadyan G.G., Nikogosyan D.N. Handbook of nonlinear optical crystals. Springer. 2013. T. 64.

[2] Wang C.R. et al. //Infrared Physics \& Technology. 2019. V 97. P 1-5. 